\title{
The evolution of lung transplantation in India and the current scenario
}

\author{
Thirugnanasambandan Sunder ${ }^{1}$ (1)
}

Received: 24 May 2021 / Revised: 26 July 2021 / Accepted: 26 July 2021 / Published online: 30 October 2021

(c) Indian Association of Cardiovascular-Thoracic Surgeons 2021

\begin{abstract}
Lung transplantation has come of age in India. This article aims to trace the evolution of lung transplantation in India from its humble beginnings in 1999 to the current scenario spanning a period of 22 years. Right from the passing of the Act legalising deceased organ transplantation, its amendments and rules - to the development of transplant regulatory bodies - both at national and state levels, the journey thus far has been chronicled. Description of the initial cases at sporadic centres which has now proliferated to many centres now across many states has been elaborated on. The impacts on evolution of lung transplantation by the governmental transplant organisations, non-governmental organisations, and the medical professional societies are described. Publications related to lung transplantation from India are mentioned. Situations specific to India, current scenario of lung transplantation, and future directions are discussed. A brief mention of our experience with lung transplantation has also been made.
\end{abstract}

Keywords Lung transplantation $\cdot$ India $\cdot$ Evolution $\cdot$ ECMO $\cdot$ COVID-19

\section{Introduction}

The Republic of India is a large country with a diverse population across 28 states and 8 union territories (UT) [1]. India ranks as the seventh largest country in the world in terms of land area and is second only to China in terms of the population size, contributing to $17.8 \%$ of the world population [2]. While the enormous task of recording and updating the official census (done once in 10 years) by the Government of India (GOI) is due only in 2021, the estimate of the size of Indian population in 2020 is about 1.38 billion (138 crores) [3].

A report on burden of chronic respiratory disease in India in the Lancet Global Health [4] suggests a disproportionately higher burden in India (32\% of the global chronic respiratory disease burden), while contributing to only $17.8 \%$ of global population. The report describes the variability of respiratory disease burden across the states of India.

Clearly, the above figures confirm the enhanced need for lung transplantation (LT) in India. While fully accomplished

Thirugnanasambandan Sunder

sunder64@gmail.com

1 Department of Heart Lung Transplantation, Apollo

Hospitals, Greams Road, Chennai 600 006, India
LT units in the country may be only a handful, India is slowly but surely coming of age as regards LT.

The article attempts to chronicle the birth and the gradual development of LT in India. To put the entire evolution in perspective, it becomes important to look at various/different aspects - all of which have a bearing and considerable impact on the evolution of LT. These include governmental transplant organisations - both at national and state levels, non-governmental organisations (NGOs), private foundations, medical professional societies, conferences, workshops, seminars, collaborative efforts, and individual building of LT units in several cities across many states. Although many of the above aspects many have occurred simultaneously or have had a time overlap - for the sake of clarity and easy narrative - these aspects are discussed under separate heads.

\section{Source material for this manuscript}

In India, while data collection and publishing in medical journals are currently improving, there is still a lot of scope for improvement. Given the relative paucity of published medical literature in India when compared to our Western counterparts, other sources of information such as websites and annual reports of governmental organisation, data from professional societies, social media, and print media 
(newspaper articles) have been used and appropriately cited. Only verifiable facts have been used to trace and list the progress of LT.

While researching for the evidence and published material on LT in India, it became apparent that there were claims -often in the print media and occasionally in medical journals - of "first" operation being performed or "first" event being organised or "first" programme either at state or national or continental level. While most of these reports were verifiable facts, occasionally there were some claims which were factually incorrect. The reason for the same is, perhaps, noticeably clear. India is a vast country and with our lamentable lack of prompt medical publishing tendency, it is very possible that events which occur in one state may not be apparent in other states. This explains the occurrence of newspaper reports or journal articles, with honourable intentions no doubt, which are at variance with the fact. Nonetheless, to the extent possible, attempts have been made to trace out the actual dates of procedures or events and to report them in correct chronological order.

\section{Narration of events}

Events regarding LT did not unfold in a uniform and progressive manner across the country. Multiple events occurred simultaneously in different parts of India; and while the progress of LT was accelerated in a few Indian states, it was not the case in other states. Narration of the unfolding events in a strict chronological manner, especially when occurring in different states of India at variable time intervals, can be challenging and often results in a text which can be confusing to the reader. To facilitate narration and for the sake of easy reading, events are grouped under separate headings of governmental (central and state) organisations, NGOs, and medical professional societies.

\section{Humble beginnings and first few cases in India}

For obvious reasons, heart transplantation (HT) and most of the LT (barring a few centres in the world which perform live related lobar LT) are performed using organs from deceased donors and legalising deceased donor organ transplantation (DDOT) was a pivotal event.

\section{Enactment of law which legalised DDOT in India: The Transplantation of Human Organs Act (THOA) 1994}

The Transplantation of Human Organs Bill (No. LIX-F of 1992) was tabled at the Upper House (Rajya Sabha) of the Indian Parliament and passed on 5 May 1993. As per protocol [5], this Bill was subsequently tabled, amended, and passed by the Lower House (Lok Sabha) of the Indian Parliament on 14 June 1994, which was again agreed to by the Rajya Sabha on 15 June 1994. It received the assent of the President of India on 8 July 1994. The THOA 1994 (Act 42 of 1994) was thus passed by the Indian Parliament [6] [7]. This Act of the Indian Parliament opened the opportunities for cardiopulmonary transplantation in India. HT led the way, with the first successful HT being done by Dr Venugopal at All India Institute of Medical Sciences (AIIMS) in 1995 .

\section{Beginnings of $L T$ in India}

In 1999, Dr. KM Cherian performed the first double-lung transplantation(DLT) and the first combined heart-lung transplantation (HLT) in India, thereby ushering in the beginning of the era of LT in India [8]. Following this initial enthusiasm, there was a decline in LT activity, until 2007, when a combined HLT was performed at Apollo Hospitals, Chennai [9]. In 2011, single lung transplantation (SLT) was first performed in in Global Hospitals in Chennai [10]. All these operations, thus far, were performed only in Chennai, the capital city of the state of Tamil Nadu.

The first SLT in state of Maharashtra was done in Hinduja Hospital, Mumbai, on 11 July 2012 [11]. The first SLT in the state of Andhra Pradesh (now Telangana) was performed in Yashoda Hospital in September 2012 [12]. In the state of Rajasthan, the first combined HLT was performed in Mahatma Gandhi Hospital, Jaipur, on 5 December 2016 [13]. In the state of Kerala, the first combined HLT was performed in Lissie Hospital, Kochi, in 6 January 2017 [14]. In the state of Karnataka, the first DLT and the first combined HLT were done in Narayana Hrudayala Hospital, Bengaluru, on 20 June 2018 [15] and 3 Jan 2019 [16], respectively.

LT procedures gradually gained momentum and more units in different states started performing LT. Detailed information of these are discussed later in the manuscript under Section "Current scenario of LT in India."

\section{Formation of governmental transplant organisations}

Following the introduction of the THOA 1994, governmental transplant organisations were formed in different states of India at different times. The states where the majority of LT and combined HLT have been performed include Tamil Nadu, Telangana (previously Andhra Pradesh), Maharashtra, and Karnataka. Other states where LT and combined HLT have been performed include Kerala, Rajasthan, Punjab, National Capital Territory (NCT) of Delhi. Hence, the 
development and formation of governmental transplant regulatory bodies only in the abovementioned states will be discussed, as they pertain to the development of LT in India. Figures 1 and 2 are maps of India depicting the states and cities where LT and combined HLT, respectively, have been done.

In the years that followed, national and regional governmental transplant organisations were formed which have had an impact on the progress of LT.

\section{National Organ and Tissue Transplant Organisation (NOTTO)}

NOTTO was established by the Ministry of Health and Family Welfare (MoHFW), GOI, in 2014 [17] as an apex body for All India activities of coordination, networking for procurement, and distribution of organs [18]. It maintains a National Organ and Tissue Transplant Registry (NOTTR). NOTTO is headquartered at Safdarjung Hospital Campus, New Delhi. The NOTTO also is the regulatory and allocating authority of organs for the National Capital Region (NCR) of Delhi. The establishment of NOTTO has had a positive impact with increase in the total number of cadaveric transplants of all organs to 10,340 in 2018 from 4990 in 2013 in India [17]. The impact of enabling legal provisions has led to an increase in organ donation and transplantation in India [19].

\section{Regional Organ and Tissue Transplant Organisation (ROTTO)}

Five ROTTOs were established in Chandigarh, Chennai, Mumbai, Kolkata, and Guwahati to serve the north, south, west, east, and northeast regions of India, respectively.

Table 1 lists the 5 ROTTOs and the States under each ROTTO [20].

\section{State Organ and Tissue Transplant Organisations (SOTTO)}

While the above 5 ROTTOs also act as SOTTOs in the respective states, the MoHFW, GOI, has also established 12 other SOTTOs in the states of Kerala, Rajasthan, Madhya Pradesh, Goa, Jammu and Kashmir, Haryana, Odisha, Gujarat, Uttar Pradesh, Bihar, Punjab, and Jharkhand [21].

\section{State governmental transplant organisations}

\section{Tamil Nadu Transplant Programme}

Tamil Nadu is the first state in India to have had a deceased donor transplant programme [22] and it led the country in terms of number of deceased organ donation, until recently. While the current global pandemic due to coronavirus disease 2019 (COVID-19) caused by severe acute respiratory syndrome coronavirus 2 (SARS-CoV-2) has reduced organ donation only recently, Tamil Nadu has been witnessing a relative decrease in organ donation rates. This is, in part, due to a remarkable decline in the deaths due to road traffic accidents, in Tamil Nadu, by 54\% since 2016 [23].

Initially, since HT and LT were sporadically performed in small numbers, there was no formal allocating authority. Reports of "kidney scams" among unfortunate victims of Tsunami (2004), who were housed in temporary tsunami camps, led to investigations and a 4-day workshop by the Government of Tamil Nadu. With a view to regulating organ donation and preventing illegal activities, a formal regulatory body, the Cadaveric Transplant Programme (CTP), was formed in 2008.

The sharp increase in deceased organ donation which occurred in 2008 has been attributed to the "Hithendran Effect" [24]. The unfortunate teenager, Hithendran, was a victim of a road traffic accident which led to his brain death in Chennai. His parents, a doctor couple, came forward to donate all his organs. The ensuing media attention and appeals by the father contributed to the spurt and sustained organ donation in the state of Tamil Nadu [25]. In 2014, the name CTP was changed to Transplant Authority of Tamil Nadu (TRANSTAN).

"The Tamil Nadu model" has been emulated by other states of India and the factors leading to the success of Tamil Nadu model has been presented at the annual conference of the International Society for Heart and Lung Transplantation (ISHLT) in 2015 [26]. Also, the historical events in the development of TRANSTAN in relation to HLT have been chronicled in detail in the Annual Report of TRANSTAN 2018-2019 [27].

\section{Telangana (previously northwestern part of Andhra Pradesh) Transplant Programme}

The newly formed state of Telangana was separated from the northwestern part of the state of Andhra Pradesh (AP) on 2 June 2014 [28]. Hyderabad, which was the capital city of the "previous" state of Andhra Pradesh, is the city where all events in relation of LT happened. It is now the capital city of newly formed Telangana; and hence, further discussion is done under the state of Telangana.

The Cadaveric Transplantation Advisory Committee (CTAC) was formed following Andhra Pradesh Government Order G.O. Rt. No.1462 dated 11 November 2009. The CTAC, during its third meeting on 3 March 2010, deliberated on various issues in relation to cadaveric transplantation and subsequently submitted its report. The 2010 CTAC report proposed a scheme for cadaveric organ transplantation called 
Fig. 1 Map of India illustrating the states (coloured and numbered) and the cities (labelled) where LT is being done. Legend: 1, Tamil Nadu; 2, Telangana; 3, Karnataka; 4, Maharashtra; 5, Punjab; 6, National Capital Territory of Delhi

Fig. 2 Map of India illustrating the states (coloured and numbered) and the cities (labelled) where combined HLT is being done. Legend: States: 1, Tamil $\mathrm{Nadu}$; 2, Telangana; 3, Kerala; 4, Karnataka; 5, Maharashtra; 6, Rajasthan

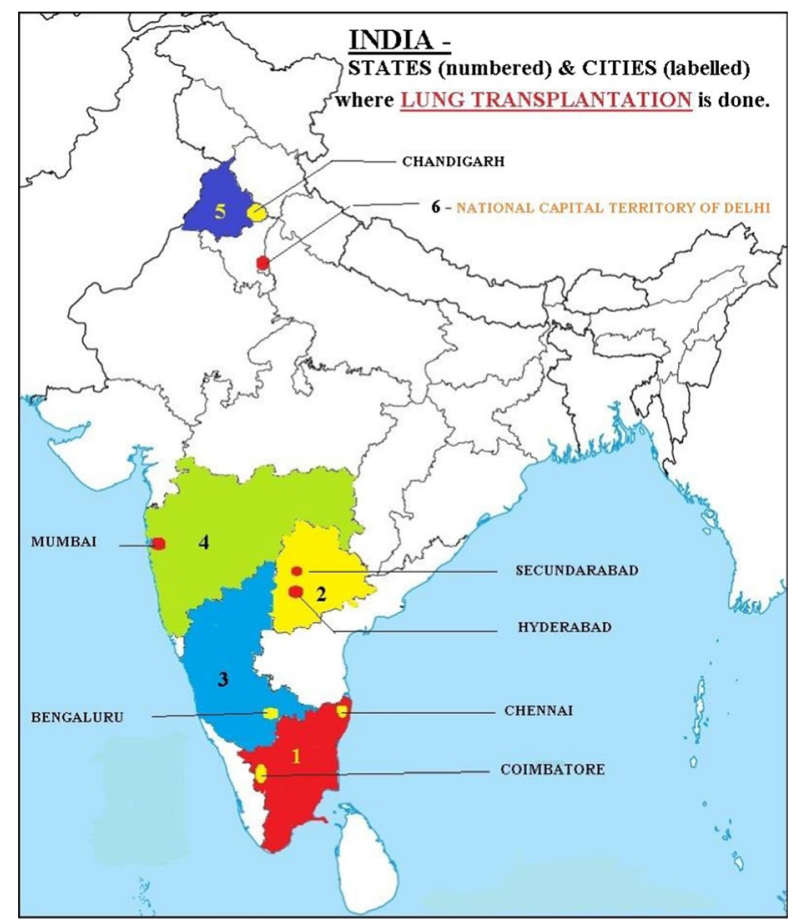

LEGEND: 1 = Tamil Nadu, 2 = Telangana, 3 = Karnataka, 4 = Maharashtra, 5 = Punjab,

\section{$6=$ National Capital Territory of Delhi.}

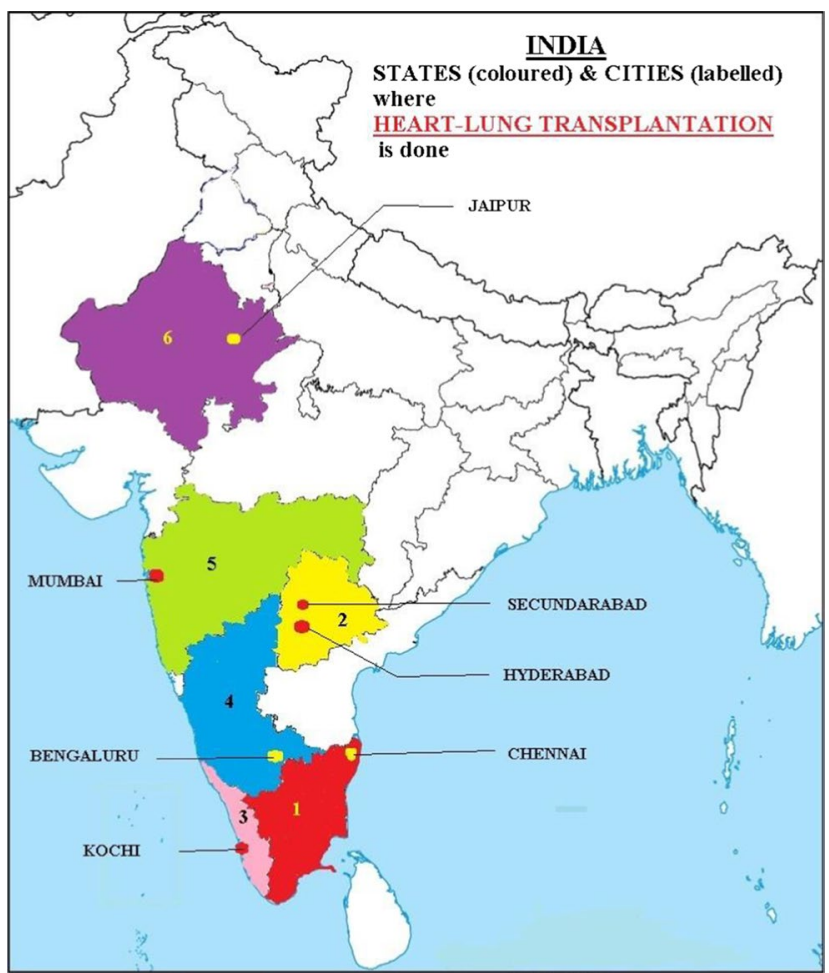

LEGEND: States: 1 = Tamil Nadu, 2 = Telangana, $3=$ Kerala, $4=$ Karnataka, $5=$ Maharashtra, 6 = Rajasthan. 
"Jeevandaan" connoting "donation of life" [29] [30]. The CTAC would be the apex regulatory body. The Appropriate Authority for Cadaveric Transplantation (AACT) would oversee the legal aspects. Andhra Pradesh Network of Organ Sharing (APNOS) formed the virtual co-ordinating mechanism. The Non-Transplant Organ Harvesting Centres (NTOHC) were authorised for retrieval of organs and Organ Transplant Centres (OTC) were licensed to perform organ transplantation.

In 2013, the proposed "Jeevandan" was launched by the AP Government. The Jeevandan programme has been performing very well and was rated as the best performing state in 2017, in terms of cadaveric organ donation rate of 4 donors per million population, as compared to India's donation rate of 0.8 donor per million population [31].

\section{Maharashtra Transplant Programme}

In Maharashtra, the state-level body to regulate and promote deceased donor transplant programme was the Maharashtra Confederation for Organ Transplant (MCFOT) which was formed in 1999. Similar regulatory bodies at zonal or city level were the Zonal Transplant Co-ordination Centres (ZTCC) which were established in Mumbai in 2000 [32], in Pune in 2004 [33], Nagpur in 2012 [34], and Aurangabad in 2015 [35].

\section{Karnataka Transplant Programme}

The Government of Karnataka established the deceased donor transplantation programme - "Jeevasarthakathe" which oversees the implementation of THOA 1994 [36]. It regulates the deceased donor programme and fair allocation of organs.

\section{Kerala Transplant Programme}

The deceased donor organ transplantation programme was an initiative of the Government of Kerala which was established on 12 August 2012 [37]. The programme was named "Mrithasanjeevani" and an organ sharing registry, Kerala
Network for Organ Sharing (KNOS), was initiated[38]. There was a decrease in the organ donation rate from 72 donors in 2015 to only 8 donors in 2018 [39]. From inception in 2012 until now, only 4 lungs have been donated in Kerala, out of which a combined HLT was performed in Kochi. The remaining 2 lungs were donated to other states.

\section{Non-governmental organisations and foundations}

There are many NGOs in India related to organ transplantation. Amongst these, the MOHAN (Multi Organ Harvest Aid Network) Foundation is the largest in India with offices in many cities in India.

\section{MOHAN Foundation}

MOHAN Foundation is a not-for-profit NGO which was started in 1997 to promote organ donation [40]. It comprises four core groups:

(i) Public Education for Organ Donation: Awareness programmes conducted all over India regularly.

(ii) Indian Transplant Newsletter - which publishes transplant-related news since 1998.

(iii) Patient Support Groups: for organ failure patients and families

(iv) Indian Network for Organ Sharing (INOS)

\section{Impact of MOHAN foundation on Indian transplant programme [41]}

The foundation has had an incredibly positive impact on organ transplantation in many states in India. It has helped develop deceased donor programmes in many states such as Tamil Nadu, Telangana, Rajasthan, and Kerala, and helped with registries and organ sharing networks — such as Tamil Nadu Network for Organ Sharing (TNOS), Rajasthan

Table 1 Organisation of ROTTO and list of states under each ROTTO

\begin{tabular}{ll}
\hline ROTTO & States under ROTTO \\
\hline ROTTO NORTH -Chandigarh & $\begin{array}{c}\text { Punjab, Haryana, Himachal Pradesh, Jammu and Kashmir, Chandigarh, Rajasthan, Uttarakhand, Uttar } \\
\text { Pradesh } \\
\text { Tamil Nadu, Kerala, Andhra Pradesh, Telangana, Karnataka, Puducherry, Andaman and Nicobar, Lak- } \\
\text { ROTTO SOUTH - Chennai }\end{array}$ \\
$\begin{array}{l}\text { Maharashtra, Gujarat, Goa, UTs of Dadra and Nagar Haveli, -Daman, Diu, Madhya Pradesh, Chhattisgarh } \\
\text { ROTTO WEST - Mumbai }\end{array}$ & West Bengal, Jharkhand, Sikkim, Bihar, Odisha \\
ROTTO EAST - Kolkata & Assam, Meghalaya, Arunachal Pradesh, Manipur, Nagaland, Mizoram, Tripura \\
ROTTO NORTH_EAST Guwahati & Delhi NCR \\
\hline
\end{tabular}

Compiled using data from NOTTO Website [20] 
Network for Organ Sharing (RNOS), and KNOS. More importantly, the foundation conducts certificate courses for transplant co-ordinators - both short-term and a yearlong course. The Indian Transplant Registry was formed and published in 2007 [42]. However, this registry provides statistical data pertaining to mainly to kidney and liver transplantation.

\section{Other NGOs and foundations}

There are more than 34 NGOs in India which work for organ donation. The list of NGOs and foundations in India, albeit not exhaustive, is available at the MOHAN foundation website [43].

\section{Impact on evolution of LT by medical professional societies}

Various professional societies described below, have had a positive, albeit slow, impact on the progress of LT by increasing the awareness and stimulating younger surgeons in taking an interest in LT. The need to include discussions on LT was felt by the professional societies, which in turn led to gradually increasing allocation of time for topics pertaining to LT, during annual conferences, both as oral presentations and orations.

Figure 3 gives a pictorial representation, by means of a line diagram, of time (in hours) allotted to LT in the annual conferences of the professional societies (listed below) over the past few years. It is apparent that over the recent years, increasing importance is given to LT, allowing more discussion and sharing of experiences which has led to the progress of LT in our country.

The professional societies include:

- Indian Association of Cardiovascular and Thoracic Surgeons (IACTS):

- Indian Society of Transplantation (ISOT):

- Society for heart failure and Transplantation (SFHFT):

- Heart Failure Association of India (HFAI):

- Indian Society for Heart and Lung Transplantation (INSHLT):

\section{Indian Society for Heart and Lung Transplantation}

The INSHLT was formed on 13 October 2017 in Indore during the $28^{\text {th }}$ Annual Conference of ISOT. A 2-day conference on Immunology in Heart and LT was organised by INSHLT in January 2019. The first Annual Conference of the INSHLT was conducted at New Delhi in October 2019. A separate hall was allotted for LT with topics and discussion lasting nearly $4 \mathrm{~h}$. The INSHLT subsequently organised a webinar on Immunogenetics in relation to HT and LT in 2021.

\section{Symposia, continuing medical education (CME) programmes, and workshops related to LT}

There have been numerous educational activities which have had an encouraging effect and have contributed to the progress of LT in our country. These educational activities and programmes have been conducted by professional bodies in association with international societies, regulatory organisations, NGOs, and individual centres.

These activities include:

(i) Symposia targeted at physicians and pulmonologists with a view to increasing the referral base.

(ii) Workshops and wet labs targeted at young surgeons and pulmonologists to invoke interest in LT.

(iii) Courses for transplant co-ordinators to sensitise them to the nuances involved in heart and lung transplantation.

(iv) Awareness programmes conducted by governmental, and NGOs directed at the public to increase awareness of organ transplantation and the benefits thereof.

\section{Physician awareness symposia and conference on LT}

With a view to increase awareness and sensitise the general physicians and pulmonologists on benefits of LT in appropriate cases and need for early referral, symposia with international faculty have been first organised by Apollo Hospitals, Chennai [44], followed by Global Hospitals, Chennai [45], and Apollo Hospitals, Hyderabad [46].

\section{Workshops and CMEs on LT for cardiothoracic surgeons and pulmonologists}

Again, to sensitise and familiarise surgeons and pulmonologists in preparation to starting a LT programme, a workshop on LT along with a human cadaveric hands-on session was conducted by the Departments of Cardiothoracic Surgery and Cardiology, AIIMS, New Delhi, in conjunction with the Department of Heart and Lung Transplantation, Apollo Hospitals, Chennai in 2018 [9, 47]. Similar wet lab surgical sessions in animal workshops with regard to HLT have been conducted in Bengaluru with international faculty from the UK. 


\section{Factors specific to India which have an impact on LT}

\section{Organ donation day}

The MoHFW launched the $6^{\text {th }}$ World Organ Donation Congress and the First Indian Organ Donation Day on 27 November 2010 in New Delhi [48]. Since then, in India, the $27^{\text {th }}$ November of each year is celebrated as Organ Donation Day to increase awareness and encourage people to pledge their organs for donation after their death [49]. The organ donation day is celebrated countrywide by respective transplant organisations felicitating the family of the donors, remembering the donors, and encouraging people to pledge their organs and register as a donor.

\section{Deceased donor organ transplantation (DDOT) in India}

The DDOT has been gradually increasing since the enactment of the THOA. Abraham et al. [50] discuss the Indian model of DDOT. Although the discussion is made with reference to renal transplantation, it is truly relevant to LT and HLT. The organ donation rate in India has been reported as 0.65 donor per million population (p.m.p) [51]. While the organ donation rate in Tamil Nadu was highest at 1.9 donors p.m.p. in 2014 [50], it was superseded by Telangana in 2017 with an organ donation rate of 4 donors p.m.p. in 2017.
The Global Observatory on Donation and Transplantation (GODT) is a joint collaboration by the Spanish Transplant Organisation (ONT) and World Health Organisation's (WHO) Service Delivery and Safety department [52]. The GODT has developed and maintains a global database of organ donation and transplantation activities. To put things in perspective, based on data from GODT [53], the organ donation rate in India has been compared with other countries (Table 2). Spain leads the rest of the world with an organ donation rate of 49.5 p.m.p. While the absolute number of donors in India is more than that of some other countries, the large population of India brings the donation rate down to 0.5 p.m.p.

\section{Impact of religious beliefs and religious leaders on LT in India}

Vast literature exists on various religions and their impact on organ donation and transplantation in India [51]. India is well known for its diversity in religious beliefs and practices. According to the most recent (2011) census figures, $79.8 \%$ of the Indian population are Hindus, $14.2 \%$ are Muslims, 2.3\% are Christians, $1.72 \%$ are Sikhs, $0.7 \%$ are Buddhists, $0.3 \%$ are Jains, and the remaining belong to other religions [54].

While there may be challenges due to religion which may impact organ donation - by and large all the religions support organ donation - the guiding principle being helping save another life is appropriate. Some religions make a distinction between living and deceased donors. Religious
Fig. 3 Graph using line diagrams to plot time allotted to discussion of topics related to LTs during annual conferences of related professional societies in India

\section{TIME (Hours) ALLOTED TO LUNG TRANSPLANTATION IN} ANNUAL CONFERENCES OF INDIAN SOCIETIES

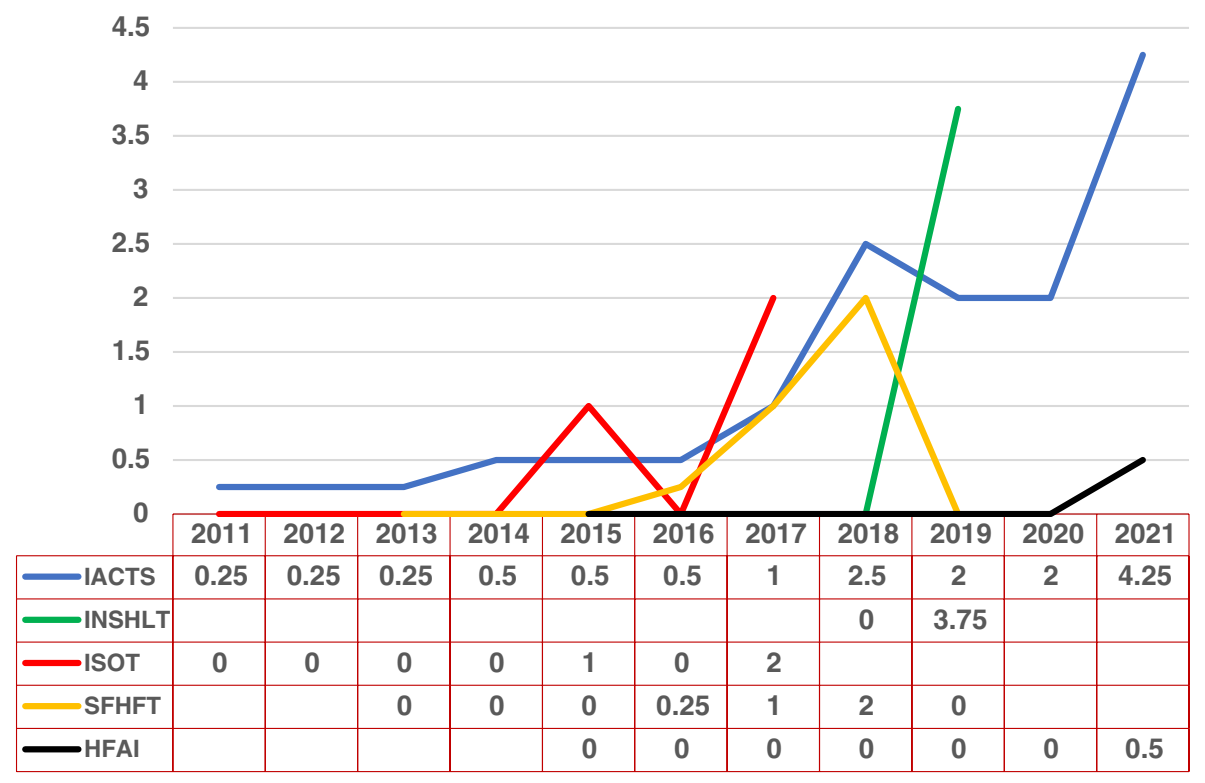


considerations in organ transplantation amongst Hindus [55], Muslims [56], and Christians [57] have been discussed elaborately in the Indian Transplant Newsletters from MOHAN foundation.

It is a well-known fact in India that religious heads possess the unquestioning trust and loyalty of their followers and devotees. The teachings and interpretations of the Scriptures by these religious heads have a profound impact on the minds of the follower. When the religious leaders are seen endorsing organ transplantation, they are accepted faithfully by the followers, but the followers required ongoing education in order to translate into organ donation [58].

In our experience, we have had recipients from all religions in India and so far have not encountered any refusal to accepting organs for transplantation based on religious reasons. Data on declining organ donation due to religious reasons are not readily available.

While there was no impact on the conduct of transplant operation itself, one instance of the effect of religious beliefs in our practice is worthy of mention. Following successful transplantation, the recipient was shifted to the intensive care unit (ICU), when there was a commotion outside. The next of kin was terribly upset that the explanted organ (heart, in this case) was not available to be buried, thereby preventing eventual salvation of the patient - as per their personal faith. He had not informed us prior to transplantation about such belief and the explanted organ had long since reached the pathology department and was not available. Discussions happened and he realised that he had not made such a specific request before the operation and eventually accepted the fact. Both the patient and his relatives were happily discharged a week later. After this incident, it is our practice to specifically ask for any special requests/beliefs during our pre-transplant counselling.

\section{Impact of tuberculosis (TB) on LT in India}

India is a TB endemic country. While end-stage lung disease following sequalae of TB being referred for $\mathrm{LT}$ is rare, the challenges due to TB often present during evaluation for candidacy in potential recipients and during donor assessments [59]. Bumbacea et al., on behalf of the Tuberculosis Network European Trials (TBNET) group, provided a consensus statement in a review article on the risk of TB in transplant candidates and recipients [60].

This review article included publications on national guidelines from UK, USA, Europe, and Canada and discusses latent TB infection (LTBI) and active TB in transplant candidates and recipients. Diagnostic and therapeutic approaches and challenges are considered in detail.

They differentiate the terms "preventive chemotherapy" (therapy given to LTBI individuals with positive immune response) and "chemoprophylaxis" (therapy to prevent TB in high-risk individuals who do not have a positive immune response).

\section{LTBI}

In India, given the prevalence of $\mathrm{TB}$, it would be appropriate to look for LTBI in all potential candidates. In our unit, all potential recipients are screened for LTBI using either Tuberculin Skin Testing (TST), e.g. Mantoux test or Interferon Gamma Release Assay (IGRA), e.g. QuantiFERONTB Gold. Those who test positive are given isoniazid prophylaxis daily for 6 months or if the recipient gets an organ - the therapy is continued posttransplant for a total of 6 months.
Table 2 Table comparing organ donation rates (donors p.m.p.) and LT activity (organs p.m.p.) for the year 2019 in selected countries worldwide

\begin{tabular}{llllll}
\hline Country & $\begin{array}{l}\text { Population (in } \\
\text { millions) }\end{array}$ & $\begin{array}{l}\text { Organ donation } \\
\text { (number) }\end{array}$ & $\begin{array}{l}\text { Organ donation } \\
\text { rate (p.m.p.) }\end{array}$ & $\begin{array}{l}\text { Lung transplant } \\
\text { (number) }\end{array}$ & $\begin{array}{l}\text { Lung transplant } \\
\text { activity (p.m.p.) }\end{array}$ \\
\hline Spain & 46.4 & 2302 & 49.6 & 419 & 9 \\
USA & 329.1 & 11,870 & 36.1 & 2759 & 8.4 \\
France & 65.5 & 1924 & 29.4 & 393 & 6 \\
Belgium & 11.6 & 321 & 27.7 & 113 & 9.7 \\
Finland & 5.6 & 145 & 25.9 & 27 & 4.8 \\
UK & 67 & 1653 & 24.7 & 167 & 2.5 \\
Australia & 25.1 & 548 & 21.8 & 183 & 7.3 \\
Germany & 82.4 & 932 & 11.3 & 361 & 4.4 \\
Denmark & 5.8 & 102 & 9.1 & 30 & 5.2 \\
China & 1428 & 5818 & 4.1 & 489 & 0.3 \\
India & 1368 & 715 & 0.5 & 114 & 0.1 \\
\hline
\end{tabular}

The data above is sorted according to decreasing order of organ donation rate. The above 2019 data are based on the Global Observatory on Donation and Transplantation (GODT) database [ref]

p.m.p., per million population 


\section{Active TB in recipients}

Definitive anti-tuberculous therapy (ATT) Post-operatively, diagnosis of TB can be challenging and demonstrations of acid-fast bacilli (AFB) or caseating granuloma and Langerhans giant cells are diagnostic. We have had one patient with weight loss, fever, and abdominal symptoms following heart-lung transplantation. Abdominal computerised tomographic (CT) scan showed large mesenteric nodes which confirmed TB on biopsy with AFB. She responded to definitive ATT. The main challenge was drug interaction between tacrolimus and rifampicin (enzyme inducer). A non-rifampicin drug regimen was used in our patient.

Empirical ATT (as a last resort-salvage therapy when no other therapy works) ATT is a prolonged therapy with numerous drug interaction, and it is commenced only when there is definitive evidence of TB. However, diagnosis of TB is not always possible. There have been instances where cautious empirical ATT has resolved symptoms of recurrent large pleural effusions which were extensively investigated with no evidence of TB and in whom no other treatment worked.

In our experience, we had a patient with unexplained high-grade fever $\left(104^{\circ} \mathrm{F}\right) 10$ days after double-lung transplantation, which lasted for 14 days during which time he was extensively evaluated. All investigations were negative and there was no response to empirical antibiotics. A positron emission tomogram (PET) scan revealed metabolically active hilar nodes with high standard uptake value (SUV) - not amenable to CT or endobronchial ultrasound (EBUS)-guided biopsy and the patient was unwilling for a video-assisted thoracoscopic surgical (VATS) biopsy. A presumptive diagnosis of donor-derived TB reactivation was made and a trial of empirical ATT resulted in total resolution of fever in 3 days. He completed his course of empirical ATT uneventfully and is now doing well.

\section{Physician awareness of LT in India}

With increasing webinars and conferences, the physician awareness on LT in India is clearly much better than a decade ago. In the metropolis, the patients are increasingly being referred appropriately; however, this practice must spread to larger groups of physician [9].

\section{Late presentation and frailty of patients in India}

Not uncommonly, in India, patients would rather endure illness than to submit themselves to surgery. In a large proportion of cases, the disease is far too gone, and frailty and cachexia set in. At this point, the patients present themselves for therapy. This is one major factor for increased need for combined HLT when compared to the Western world. Patients with end-stage heart or lung failure present very late - when an isolated HT or LT is not appropriate and hence require combined HLT [9].

\section{Geographical aspects of India}

India is a vast country and long distances must be covered to reach the transplant centre which increases the ischaemic times. Air ambulances can be expensive and not always available and proves to be a challenge [61].

\section{Financial considerations of LT in India}

Patients often have to self-fund for the LT which can be an expensive treatment. Transplant operations are performed free of charge in government hospitals. Government-sponsored insurance schemes in many states assist the patients in having the operation in a private centre. When complications occur or prolonged ICU stay with long periods of rehabilitation is required, the financial burden to the patient can be significant.

\section{Current scenario of LT in India}

The INSHLT has embarked on the task of collecting data related to heart and lung transplantation and compiling them in a registry - INdian TRANsplant Registry (INTRAN) [62]. This is a prospective database with voluntary contribution of data regarding HT, LT, and combined HLT from individual units across India. Data from the INTRAN has been used to compile the forthcoming description, graphs, and pie charts.

Five states/UT in India have centres performing isolated LT and combined HLT. At the time of writing this manuscript, 339 isolated LTs have been performed in 5 states/UT, namely Tamil Nadu, Telangana, Karnataka, Maharashtra, Punjab, and Union Territory of Delhi; and 102 HLTs have been performed in 6 states, namely Tamil Nadu, Telangana, Kerala, Karnataka, Maharashtra, and Rajasthan.

Data from INTRAN, registries aided and maintained by MOHAN foundation including sources, form TRANSTAN and TNOS, Jeevandan, and ZTCC Mumbai, has been used to compile charts. However, there exists some discrepancy between data on the website and data from INTRAN which is voluntarily provided by individual centres. This may largely be because a pair of lungs is varyingly counted as either 1 (donor) or 2 (organs) for every pair of lungs donated and the fact that patients with both SLT and DLT are reported as 1 . While the data in INTRAN is vigorously checked and corrective steps taken, whenever necessary, it is also entirely conceivable that minor errors during voluntary 
a

LUNG TRANSPLANTATION (SLT,DLT,HLT)

IN THE STATE OF TAMIL NADU-YEARWISE DISTRIBUTION

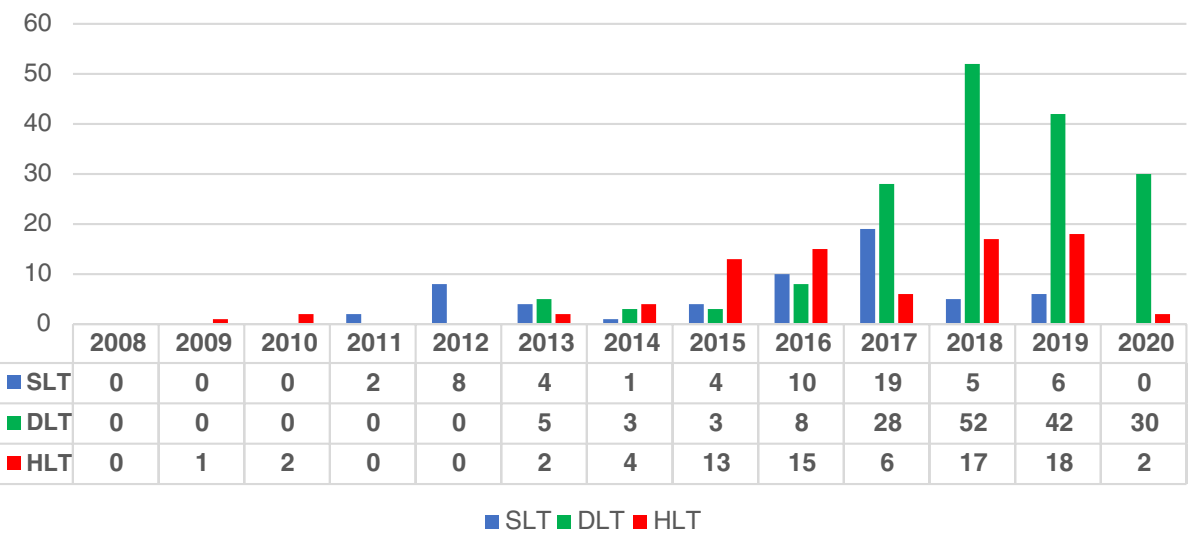

b

\section{LUNG TRANSPLANTATION (LT +HLT) \\ IN THE STATE OF TELANGANA \\ YEAR-WISE DISTRIBUTION}

\section{5}

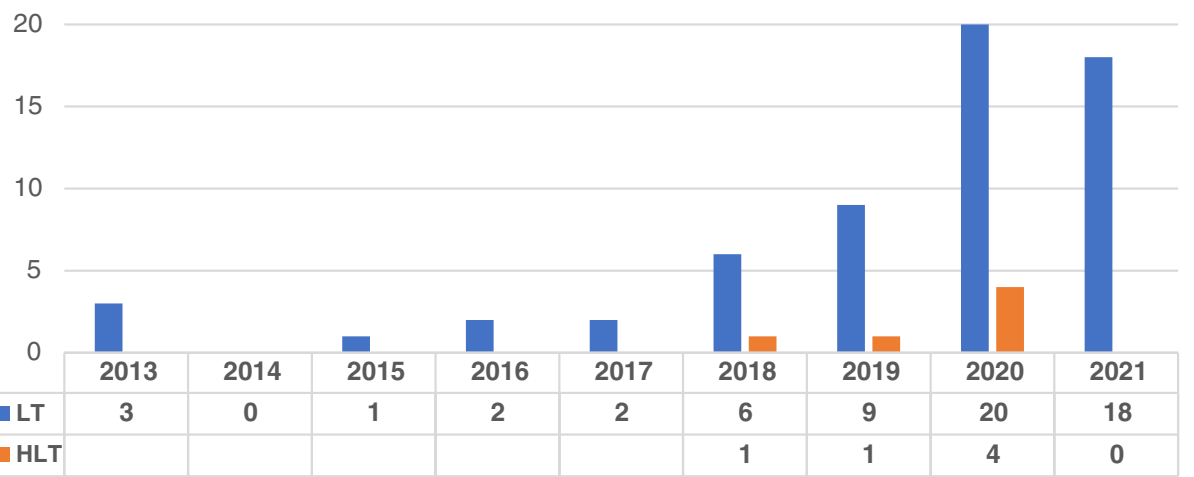

$$
\square \mathrm{LT} \backsim \mathrm{HLT}
$$

C

LUNG TRANSPLANTATION (LT and HLT)

IN STATE OF MAHARASHTRA

YEAR-WISE DISTRIBUTION

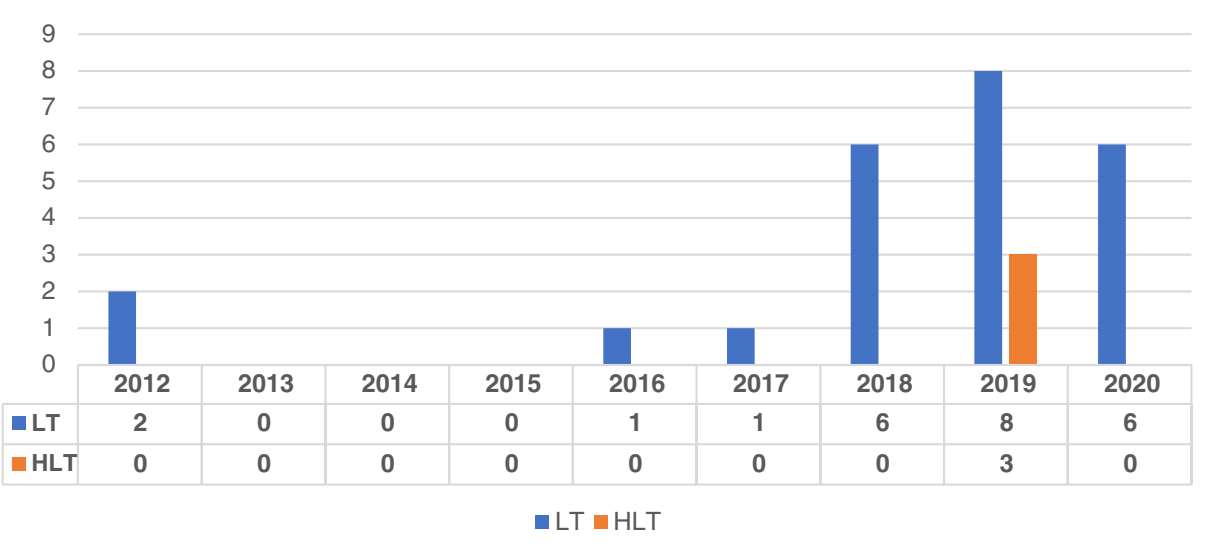


4Fig. 4 a Clustered columns depicting number of LTs year-wise from 2008 until 2020 in the state of Tamil Nadu. The chart was compiled using data from TRANSTAN website [60] https://transtan.tn.gov.in/ statistics.php. b Year-wise distribution of LT (LT + HLT) from 2013 until 2021 in the state of Telangana. The charts were compiled using data from INTRAN [59] and Jeevandan [61]. https://www.jeevandan. gov.in/organstatistics.htm. c Year-wise distribution of LTs and HLTs in the state of Maharashtra illustrated by clustered columns from year 2012 until 2020. This chart is compiled using data from the ZTCC website, Mumbai [62]. https://www.ztccmumbai.org/data.html

recording of data might creep in. The lack of distinction between SLT and DLT compounds the problem. Furthermore, websites of some state organisations provide data only until 2020, while the INTRAN is up to date.

\section{Statewise performance of LT and HLT in India}

\section{Tamil Nadu-current scenario}

Two cities in Tamil Nadu - Chennai and Coimbatorehave centres which perform isolated LT and combined HLT. A total of 257 isolated LTs (including SLT and DLT) and 83 combined HLTs have been performed in Tamil Nadu. Of the 257 isolated LTs, 252 isolated LTs were performed in Chennai, while 5 isolated LTs were performed in the city of Coimbatore. All the 83 combined HLTs were performed in the city of Chennai. Figure 4a shows clustered chart depicting the number of LT done in Tamil Nadu - year-wise from 2008 until 2020. In Tamil Nadu, the break-up of number of LT into the various types - SLT, DLT, and HLT - is available. There has been progressive increase in the number of LTs from 2011 with the maximum number in 2018. The majority of isolated LT performed are DLT. Of note are the high numbers of combined HLT performed when compared to that of the Western literature. The decline in the numbers in 2020 is because of the global COVID-19 pandemic.

\section{Telangana (previously Andhra Pradesh) — current scenario}

Two cities-Hyderabad and Secundarabad - have centres which perform LT and HLT in state of Telangana. Thirtyeight isolated LTs (33 in Hyderabad and 5 in Secundarabad) and 7 combined HLTs (5 in Hyderabad and 2 in Secundarabad) have been performed in Telangana.

Figure $4 \mathrm{~b}$ depicts the number of isolated LT and combined HLT year-wise from 2013 until 2021 in Telangana using clustered columns. There has been a gradual and progressive increase in the number of isolated LT from 2013 onwards. While data on combined HLT are separately available, data on the number of SLT and DLT separately is not available.
Maharashtra-current scenario

In Maharashtra, after an initial start with 2 isolated LTs in 2012 , there was a period of inactivity until 2016. The numbers of isolated LTs then progressively increased from 2018. The effect of COVID pandemic caused a fall in the numbers in 2020 (Fig. 4c). Based on data from INTRAN, a total of 24 isolated LTs and 6 combined HLTs were performed in the state of Maharashtra, all in the city of Mumbai, until 2021.

\section{Karnataka - current scenario}

In Karnataka, a total of 27 isolated LTs and 2 combined HLTs have been done, all in the city of Bengaluru. Year-wise breakdown of data was not readily available to create a chart.

\section{Other remaining states in India}

In Delhi, one isolated SLT has been performed and one combined HLT has been performed in each of the states of Kerala (Kochi) and Rajasthan (Jaipur).

\section{Consolidated data on LT and HLT for India}

\section{Consolidated data (a): total number of LTs and HLTs in India- year-wise distribution}

A total of 339 isolated LTs and combined 102 HLTs have been done in India until March 2021. The details of exact proportion of SLT and DLT are currently not available. Figure 5 depicts a clustered chart showing the numbers of isolated LTs and combined HLTs done in India over the years from 2008 to 2021 . The number of isolated LTs has been progressively increasing, reaching the maximum in the last 3 years. The number of HLTs, on the other hand, has remained the same in the last few years. Since the year-wise distribution of the LTs in the state of Karnataka is not available, their data are not included in Fig. 5.

\section{Consolidated data (b): total number of LTs and HLTs in India- state-wise distribution}

Figure 6 depicts stacked columns for ALL types of LT (for SLT, DLT, and HLT) illustrating state-wise distribution in India. Of the total number of 441 transplants (isolated $\mathrm{Lt}+$ combined HLT) in India, 340 transplants were performed in Tamil Nadu, 45 transplants in Telangana, 29 transplants in Karnataka, 23 transplants in Maharashtra, and 1 each in the states of Punjab, Rajasthan, Kerala, and UT of Delhi have been performed. 


\section{Centres performing isolated LTs and combined HLTs in India}

There are 18 centres in India performing isolated LTs. Of these 18 centres, 9 centres have performed less than 5 isolated LTs each. Table 3 lists the hospital/centre, city, and state along with the number of isolated LTs performed thus far in India.

There are 15 centres in India which have performed combined HLT. Of these, 12 centres have performed less than 7 combined HLTs each, which includes 7 hospitals which have done 1 combined HLT. Table 4 lists the hospital/centre, city, and state along with the number of combined HLTs performed thus far in India.

\section{Publications regarding LT from India}

Publications in India have largely been case reports of HLT [8] and LT [10], with some reports describing LT in rare conditions such as Hermansky Pudlak syndrome [63] and pulmonary alveolar microlithiasis [64]. The first LT to be done in a government (public sector) hospital, although unsuccessful, was reported in 2019 from Chandigarh [65]. The same group published data on underutilisation of donor lungs [66] and on profile of patients being referred for LT in North India [67]. There is even a case report on a routine LT done in a private centre for a recipient from Armed Medical Services [68]. Anaesthetic considerations for LT [69] and donor management in HLT [70] have also been reported. There are descriptive case series of SLT, DLT, and HLT [61] [71]. MGM Hospitals Chennai participated in a multi-institutional report on a case series of LT in COVID19 which was published in March 2021, having contributed 1 case of a total of 12 cases from 4 institutions across the world [72]. Experience with bridge to transplantation (BTT) using extra-corporeal membrane oxygenation (ECMO) has been reported in a review article recently [73].

\section{Reports of survival analysis following LT in India}

In India, the first ever survival analysis using Kaplan-Meier curves for a 3-year period following LT was published by Apollo Hospitals, Chennai, in 2020 [47]. The 3-year survival following isolated LT in 47 patients was reported to be $76.2 \%$. Patients who underwent SLT and combined HLT were not included in the analysis.

Subsequently, in 2021, Gleneagles Hospitals, Chennai, reported survival analysis using Kaplan-Meier curves. Survivals of $85 \%$ and $78 \%$ at 1 month and 1 year respectively were reported [74]. The analysis included combined outcomes of SLT (7 patients), DLT (106 patients), and HLT (19 patients) performed in a 3-year period among a total of 132 patients performed in 3 centres in the cities of centres in Chennai, Bengaluru, and Mumbai. The ages ranged from 16 to 71 years (mean age $48.6+/-13.45$ ) among 73 male patients and 59 females with a sex ratio 1.24:1 (M:F).

All patients were followed up for 30 days. Interstitial lung disease (ILD), most commonly hypersensitivity pneumonitis (HSP) and idiopathic pulmonary fibrosis (IPF), was the commonest diagnosis in their series $(65.91 \%)$, followed by bronchiectasis $(9.85 \%)$ and idiopathic pulmonary arterial hypertension (IPAH) (6.82\%). Prior to LT, eight patients were bridged with mechanical ventilation and 14 were bridged using ECMO. Clamshell incision (104 patients) was the most used incision for DLT. Fifty-six patients were operated on without use of extra-corporeal circulatory support; intraoperative cardiopulmonary bypass (CPB) support was used in $42.3 \%$ of patients and ECMO in $14.2 \%$. Primary graft dysfunction (PGD) grade 3 was seen in 16 patients. Airway complications (68 patients) included distal airway stenosis (21 patients), anastomotic stenosis (19 patients), and dehiscence (7 patients). Thirty-four patients had acute cellular rejection (ACR) including 1 case of hyperacute rejection, 3 patients had antibody-mediated rejection (AMR) and chronic rejection each. The commonest cause of mortality at 30 days $(n=19)$ and 1 year $(n=26)$ was sepsis $(63.5 \%$ and $52 \%)$, followed by severe PGD (15.8\% and $12 \%)$ respectively. Other causes included ACR, AMR, and gastro-intestinal (GI) bleed among others.

\section{Impact of COVID-19 pandemic on LT in India}

The COVID-19 pandemic caused by SARS-CoV-2 resulted in a nationwide lock down in India on 24 March 2020, which lasted until 31 May 2020 [75]. Following this, there was temporary suspension of deceased donor transplant in India [76] which was then subsequently re-commenced. The first DLT, during COVID pandemic times, in a non-COVID endstage ILD patient, was performed in Tamil Nadu in July 2020. Another patient was successfully bridged to DLT using ECMO for 46 days [77]. The INSHLT has published recommendations for thoracic organ transplantation during COVID pandemic [78].

In India, the first LT for COVID-affected lungs was performed on 24 August 2020 in the city of Hyderabad [79], Telangana. In Tamil Nadu, the first LT for COVID-affected lungs was performed on 27 August 2020 [80]. This was followed by a LT for COVID-affected lungs in Delhi, which also happened to be the first LT to be done in New Delhi [81].

So far, based on collective data from INTRAN, newspaper articles, and personal communications, it appears that around 25 LTs have been done in India for COVID-affected lungs. This includes patients whose previously normal lungs were ravaged by COVID and patients with end-stage lung 
Fig. 5 Year-wise distribution of consolidated total of LT $(\mathrm{LT}+\mathrm{HLT})$ in India from year 2007 until 2021 using clustered columns.. The consolidated chart is compiled using data from TRANSTAN, Jeevandan, ZTCC, and INTRAN. These clustered columns do not include the LTs and HLTs done in Karnataka as year-wise data is not available

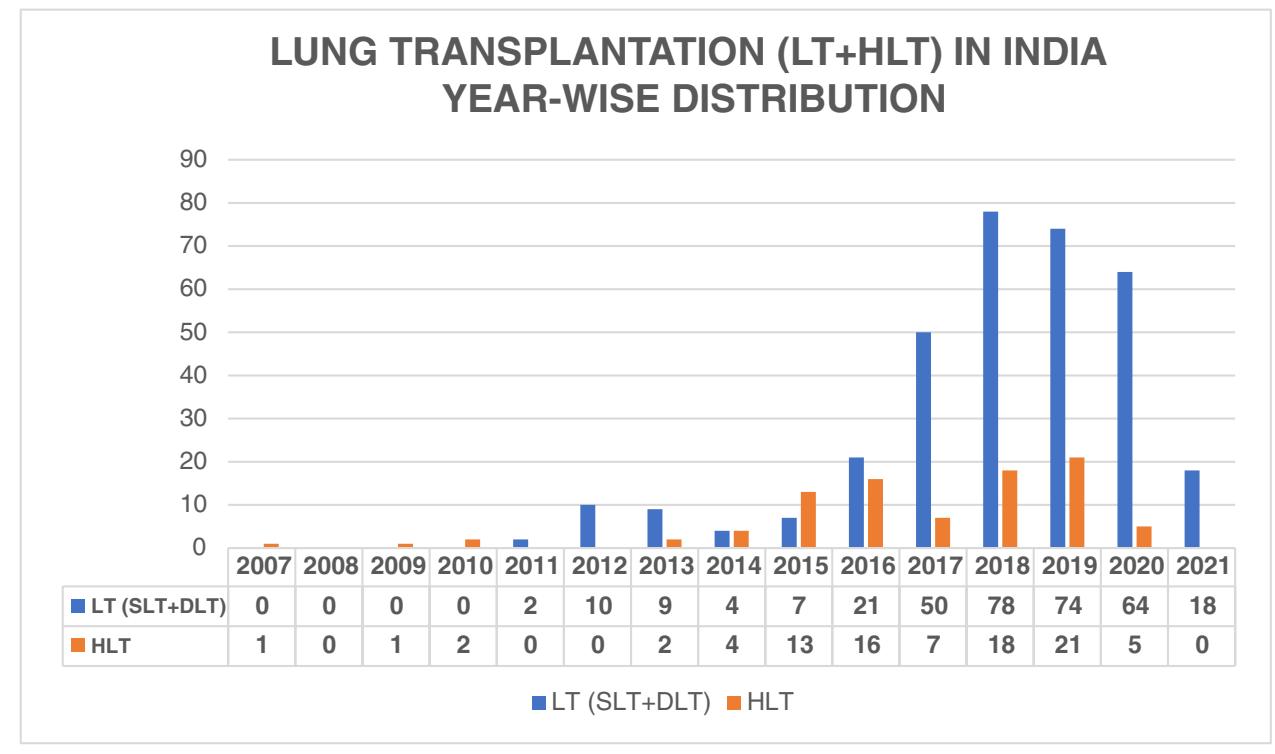

Fig. 6 State-wise distribution of all types of lung transplants (LTs + HLT) using a stacked column for each state. These columns have been created using data from TRANSTAN, Jeevandan, ZTCC Mumbai, and INTRAN

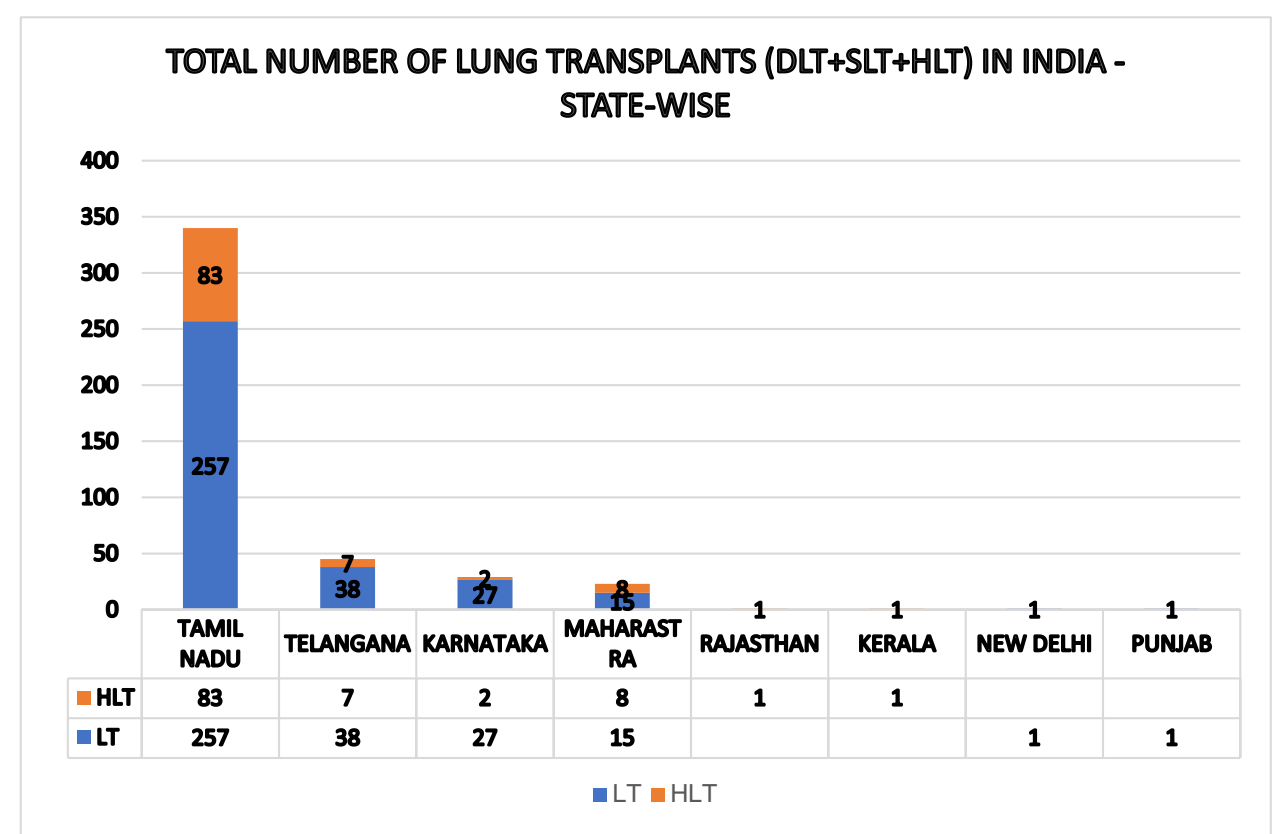

disease which worsened with superadded COVID infection. However, the outcomes following LT for COVID in India are currently not yet available.

\section{Our experience}

We performed our first combined heart-lung transplantation in 2007, our first SLT in 2011, and our first DLT in 2013. To date, we have performed 58 isolated LTs out of which 51 were DLT and 7 were SLT. In addition, we have performed 29 combined HLTs which also includes 1 patient who underwent combined heart -lung and kidney transplantation. The 3-year survival following DLT is 76.2\% [47].

Amongst all the 87 patients who underwent SLT, DLT, and HLT in our unit, 53 patients were males and 34 were female patients with a sex ratio of 1.6:1 (M:F). The mean age was 48 years $+/-13.9$, ranging from 19 to 72 years. Most patients requiring LT are patients with end-stage lung disease due to ILD (84\%). Less common diagnosis includes chronic obstructive pulmonary disease (COPD) (10\%) and bronchiectasis (5\%). The indications for HLT in our series were ILD with end stage heart disease $(37.9 \%)$, IPAH (34.5\%), bronchiectasis (10.3\%), congenital heart disease $(6.9 \%)$, COPD (3.4\%), and ischaemic 
Table 3 Hospitals performing lung transplantation in India (data from INTRAN registry)

\begin{tabular}{|c|c|c|c|c|}
\hline No & Hospital name & City & State & $\begin{array}{l}\text { Number of lung } \\
\text { transplantation } \\
\text { done }\end{array}$ \\
\hline 1 & Gleneagles Global Health City & Chennai & Tamil Nadu & 121 \\
\hline 2 & Apollo Hospitals, Greams Road & Chennai & Tamil Nadu & 57 \\
\hline 3 & Fortis Malar Hospital & Chennai & Tamil Nadu & 36 \\
\hline 4 & KIMS Hospital & Hyderabad & Telangana & 31 \\
\hline 5 & BGS Gleneagles Global Hospital & Bengaluru & Karnataka & 21 \\
\hline 6 & Frontier Lifeline Hospital & Chennai & Tamil Nadu & 19 \\
\hline 7 & MGM Hospital & Chennai & Tamil Nadu & 19 \\
\hline 8 & Global Hospital, Parel & Mumbai & Maharashtra & 11 \\
\hline 9 & Yashoda Hospitals & Secunderabad & Telangana & 5 \\
\hline 10 & Narayana Hrudayala Hospital & Bengaluru & Karnataka & 4 \\
\hline 11 & PSG Hospital & Coimbatore & Tamil Nadu & 3 \\
\hline 12 & Apollo Hospitals, Jubilee Hills & Hyderabad & Telangana & 2 \\
\hline 13 & Fortis Hospital, Mulund & Mumbai & Maharashtra & 2 \\
\hline 14 & Kovai Medical Centre Hospital & Coimbatore & Tamil Nadu & 2 \\
\hline 15 & Aster CMI Hospital & Bengaluru & Karnataka & 2 \\
\hline 16 & PGIMER & Chandigarh & Punjab & 1 \\
\hline 17 & $\begin{array}{l}\text { Kokilaben Dhirubhai Ambani } \\
\text { Hospital }\end{array}$ & Mumbai & Maharashtra & 1 \\
\hline 18 & Max Hospital, Saket & New Delhi & New Delhi & 1 \\
\hline 19 & HN Reliance Hospital & Mumbai & Maharashtra & 1 \\
\hline $\begin{array}{l}\text { Total number of } \\
\text { LTs in India }\end{array}$ & & & & 339 \\
\hline
\end{tabular}

Table 4 List of hospitals performing combined heartlung transplantation (data from INTRAN registry)

\begin{tabular}{lllll}
\hline No & Hospital Name & City & State & $\begin{array}{l}\text { Number of heart-lung } \\
\text { transplantations done }\end{array}$ \\
\hline 1 & Apollo Hospitals, Greams Road & Chennai & Tamil Nadu & $29 *$ \\
2 & Fortis Malar Hospital & Chennai & Tamil Nadu & 25 \\
3 & Gleneagles Global Health City & Chennai & Tamil Nadu & 21 \\
4 & Fortis Mulund & Mumbai & Maharashtra & 7 \\
5 & Frontier Lifeline Hospital & Chennai & Tamil Nadu & 4 \\
6 & KIMS Hospital & Hyderabad & Telangana & 4 \\
7 & MGM Hospital & Chennai & Tamil Nadu & 3 \\
8 & Yashoda Hospitals & Secundarabad & Telangana & 2 \\
9 & Apollo Hospitals, Jubilee Hills & Hyderabad & Telangana & 1 \\
10 & Narayana Hrudayala Hospital & Bengaluru & Karnataka & 1 \\
11 & Rajiv Gandhi Govt. General Hospital & Chennai & Tamil Nadu & 1 \\
12 & Aster CMI Hospital & Bengaluru & Karnataka & 1 \\
13 & Global Hospital, Parel & Mumbai & Maharashtra & 1 \\
14 & Lisie Hospital & Kochi & Kerala & 1 \\
15 & Mahatma Gandhi Hospital & Jaipur & Rajasthan & 1 \\
Total & number & & &
\end{tabular}

*Includes 1 patient with combined heart-lung and kidney transplantation 
cardiomyopathy with irreversible pulmonary hypertension (6.9\%). The relatively higher incidence of combined HLT in our patients is because of late presentation of patients with end-stage heart failure and end-stage lung failure, when isolated HT or LT would not suffice, and patients often need combined HLT.

\section{Changing practices and evolution of our immunosuppression protocol}

This has evolved over the last 14 years. Our first combined HLT had induction therapy with rabbit anti-thymocyte globulin (R-ATG) and methyl prednisolone with added dose of methyl prednisolone just prior to release of the clamp. This was followed by maintenance triple therapy with tacrolimus, mycophenolate, and steroid. The patient was extubated uneventfully $14 \mathrm{~h}$ later and was well for 3 days. He then developed a rapidly progressive fulminant pneumonia and succumbed within $24 \mathrm{~h}$ of onset of pneumonia. This led us to review our practice and in our patients, we realised that infection was a bigger problem than rejection. We strictly regulated our infection control practices with rigid protocols, which was developed over the next few years, confining ourselves to heart transplantation. We also suitably adjusted immunosuppressive regimens, finding a right balance.

We recommenced SLT in 2011 using mycophenolate $2 \mathrm{~g}$ which was given orally just prior to shifting to theatre, followed by maintenance triple therapy with success. This regimen was satisfactory for years. We then encountered 3 cases of chronic lung allograft dysfunction (CLAD) after 3 to 4 years after transplantation, which consisted of 2 cases of bronchiolitis obliterans syndrome (BOS) and 1 case of restrictive allograft syndrome (RAS). By this time, we had accrued adequate experience in streamlining infection control processes and as a safeguard against development or delaying the onset of BOS, we started using IL2 receptor antagonist basiliximab on induction (day 0 ) and day 4 in addition to our triple therapy.

\section{Our current immunosuppression regimen}

In routine "non-sensitised" patients, we use $20 \mathrm{mg}$ of basiliximab (day 0 dose) along with $500 \mathrm{mg}$ methylprednisolone during anaesthetic induction. Two further doses of IV methyl prednisolone are given prior to release of each lung into circulation. Maintenance triple therapy (tacrolimus, mycophenolate, and prednisolone) commenced as soon as possible. Further dose of $20 \mathrm{mg}$ basiliximab is given on day 4 .

Our experience with TB has been briefly touched upon earlier in section "Impact of tuberculosis (TB) on LT in India". The leading cause of mortality in our patients was sepsis.

\section{Future directions and journey ahead}

In terms of clinical aspects of LT, there are a handful of accomplished and mature units performing routine and complex LT cases, including ECMO bridge to LT as well as managing post-transplant graft rescue therapy with ECMO.

The immediate goal, perhaps, should be to improve on the quality of data maintained in our INTRAN registry. Currently, only numbers of procedures by various hospitals are recorded. Distinction between SLT and DLT must be made. Outcome analysis and analysis of risk factors for morbidity in Indian context are needed.

In due course, given the scarcity of donor organs, measures to increase donor pool such as ex vivo lung perfusion and donation after cardiac death (DCD), which have been discussed in many webinars and meetings, need to be worked on. DCD will require legislative approval. Living donor lobar lung transplantation is yet another aspect of LT which could obviate the long waiting period in appropriate patients and must be considered.

Funding None.

Availability of data and material Available at request.

Code availability Not applicable.

\section{Declarations}

Conflict of interest The author declares no competing interests.

Ethics approval Not required as it is a review article.

Informed consent to participate Not applicable as it is a review article.

Informed consent for publication Not applicable as it is a review article.

\section{References}

1. States of India I National Portal of India [Internet]. [cited 2021 Apr 14]. Available from: https://www.india.gov.in/india-glance/ states-india

2. India - Wikipedia [Internet]. [cited 2021 Apr 14]. Available from: https://en.wikipedia.org/wiki/India

3. Population estimates by Aadhar [Internet]. [cited 2021 Apr 14]. Available from: https://uidai.gov.in/images/state-wise-aadhaarsaturation.pdf

4. Salvi S, Kumar GA, Dhaliwal RS, et al. The burden of chronic respiratory diseases and their heterogeneity across the states of India: the Global Burden of Disease Study 1990-2016. Lancet Glob Heal [Internet]. Elsevier Ltd; 2018 [cited 2021 Apr 14];6:e1363-74. Available from: https://doi.org/10.1016/ S0140-6736 
5. How a Bill becomes an Act [Internet]. Lok Sabha Secr. New Delhi. 2014 [cited 2021 Apr 24]. Available from: http://164. 100.47.194/our parliament/How a bill become an act.pdf

6. HOTA act [Internet]. [cited 2021 Apr 24]. Available from: https://isot.co.in/hota_act

7. - G of I, Ministry of Law J and CA. Transplantation of Human Organs Act, 1994 [Internet]. 1994 [cited 2021 Apr 20]. Available from: https://main.mohfw.gov.in/sites/default/files/Act 1994.pdf

8. Madhu Sankar N, Kurian VM, Rajan S, Ninan B, Ajit M, Cherian KM. Heart-lung transplantation in India: Initial experience. Indian Heart J. 2003;55:185-7.

9. Sunder T, Ramesh TP, Kumar KM, Suresh M, Singh S, Seth S. Lung transplant: the Indian experience and suggested guidelines part 1 selection of the donor and recipient. J Pract Cardiovasc Sci [Internet]. Medknow; 2018 [cited 2021 Apr 13];4:88. Available from: http://www.j-pcs.org/text.asp?2018/4/2/88/240968

10. Elumalai RS, Somasundaram G, Vaidyanathan K, Venkatraman R, Nainar M, Rahulan V. Single lung transplantation in India: an initial experience. Indian J Chest Dis Allied Sci. 2013;55:101-3.

11. Mumbai woman is India's 1st to get lung transplant I Mumbai News - Times of India. Times of India [Internet]. Jul [cited 2021 Apr 23];2012. Available from: https://timesofindia.indiatimes. $\mathrm{com} / \mathrm{city} / \mathrm{mumbai} / \mathrm{mumbai}$-woman-is-indias-1st-to-get-lung-trans plant/articleshow/15284769.cms

12. Lung transplant gives new lease of life to woman - The Hindu BusinessLine [Internet]. 2012 [cited 2021 Apr 23]. Available from: https://www.thehindubusinessline.com/news/Lung-trans plant-gives-new-lease-of-life-to-woman/article20504664.ece

13. Heart-lung transplant: Jaipur hospital does a first I Jaipur News Times of India [Internet]. Times of India. 2016 [cited 2021 Apr 23]. Available from: https://timesofindia.indiatimes.com/city/ jaipur/heart-lung-transplant-jaipur-hospital-does-a-first/artic leshow/55826734.cms

14. Kerala achieves its first 'heart-lung transplantation- The New Indian Express [Internet]. New Indian Express. 2017 [cited 2021 Apr 23]. Available from: https://www.newindianexpress.com/cities/kochi/2017/jan/16/kerala-achieves-its-first-heart-lung-trans plantation-1560216.html

15. Hina. Case of first ever double lung transplant of Karnataka [Internet]. Med. Dialogues. 2018 [cited 2021 Apr 23]. Available from: https://speciality.medicaldialogues.in/case-of-first-ever-doublelung-transplant-of-karnataka

16. Senior citizen undergoes first heart and lung transplant in Karnataka I Bengaluru News - Times of India [Internet]. Times of India. 2019 [cited 2021 Apr 23]. Available from: https://times ofindia.indiatimes.com/city/bengaluru/senior-citizen-undergoesfirst-heart-and-lung-transplant-in-ktaka/articleshow/67427621. $\mathrm{cms}$

17. Vasanthi R. Why NOTTO? The National Organ and Tissue Transplant Organisation and Why It Is Crucial to Regulate Organ Donation and Transplantation in India. Transplant Proc [Internet]. Elsevier Inc.; 2020 [cited 2021 Apr 24];52:2930-3. Available from: https://pubmed.ncbi.nlm.nih.gov/32605769/

18. Organisation NO and TT. About us : NOTTO [Internet]. [cited 2021 May 7]. Available from: https://notto.gov.in/about-us.htm

19. Ramesh V, Singh P. Enabling legal provisions and their crucial role in promoting organ donation and transplantation - the Indian scenario. Transplantation [Internet]. Ovid Technologies (Wolters Kluwer Health); 2020 [cited 2021 Apr 27];104:S282-S282. Available from: https://journals.lww.com/https://doi.org/10.1097/01.tp. 0000699916.95260.a4

20. ROTTO: NOTTO: Rotto Details [Internet]. [cited 2021 May 7]. Available from: https://www.notto.gov.in/Rottos.htm

21. Ministry of Health and Family Welfare- Government of India. National Organ Donation Day celebration [Internet]. Press Inf.
Bur. 2020 [cited 2021 May 8]. Available from: https://pib.gov.in/ PressReleasePage.aspx?PRID $=1676491$

22. Shroff S, Rao S, Kurian G, Suresh S. Organ donation and transplantation-The Chennai experience in India. Transplant Proc.2007;39:714-8.

23. Dipak K Dash. Tamil Nadu shows way in reducing road deaths by nearly $54 \%$ in 4 years I India News [Internet]. The Times of India. Chennai; 2021 [cited 2021 Apr 22]. Available from: https://times ofindia.indiatimes.com/india/tamil-nadu-shows-way-in-reducingroad-deaths-by-nearly-54-in-4-years/articleshow/80334919.cms

24. Snigdha Basu. "Hithendran Effect" keeping Tamil Nadu at the forefront of organ donation [Internet]. NDTV. 2017 [cited 2021 Apr 22]. Available from: https://www.ndtv.com/health/hithe ndran-effect-keeping-tamil-nadu-at-the-forefront-of-organ-donat ion-1659513

25. Ashokan.S. A P Hithendran Memorial Trust [Internet]. 2009 [cited 2019 Jul 17]. Available from: http://www.aphithendranmem orialtrust.org/home.html

26. Thangaraj PR, Amalopavanatham J, Kuppuswamy MK, Thirugnanasambandan S. Comparison of heart and lung transplantation rates between 1994-2004 and 2004-2014_factors responsible for the success of Tamilnadu State model [Internet]. J. Hear. Lung Transplant. 2015. Available from: https://www.jhltonline.org/artic le/S1053-2498(15)00454-4/pdf

27. Sunder T, Paul Ramesh T, Madhan Kumar K. "TRANSTAN and Heart-Lung Transplantation in TamilNadu - the journey so far...." TRANSTAN Annu Rep. Chennai: Governent of Tamil Nadu; 2019. p. 56-62.

28. Telangana - Wikipedia [Internet]. [cited 2021 Apr 27]. Available from: https://en.wikipedia.org/wiki/Telangana

29. The Cadaver Transplantation Advisory Committee. Report of The Cadaver Transplantation Advisory Committee (CTAC) [Internet]. [cited 2021 Apr 27]. p. 1-37. Available from: https://dme.ap.nic. in/cadaver/cadaver_transplantation_report.pdf

30. P Samuel Jonathan. Awareness about organ donation can save many lives - [Internet]. The Hindu. 2015 [cited 2021 Apr 27]. Available from: https://www.thehindu.com/news/national/andhrapradesh/awareness-about-organ-donation-can-save-many-lives/ article6972855.ece

31. Bhatia A, Bhaskar S. Telangana sets an example on National Organ Donation Day 2017. Here's What The State Is Doing Right I Features. NDTV Digit news Publ [Internet]. 2017 Nov 27 [cited 2021 May 9]; Available from: https://sites.ndtv.com/ moretogive/telangana-sets-example-national-organ-donat ion-day-2017-heres-state-right-2225/

32. ZONAL TRANSPLANT CO-ORDINATION CENTRE [Internet]. [cited 2021 May 9]. Available from: https://www.ztccmumbai.org/ history_ztcc.php

33. Navin S. A Pathbreaker in Pune - Mrs. Arati Gokhale, Central Coordinator, ZTCC - Pune. Indian Transpl Newsl. 2018;17.

34. Zonal Transplant Coordination Center - Nagpur [Internet]. [cited 2021 May 11]. Available from: http://www.Ztccnagpur.org/ztccnagpur.html

35. Aurangabad ZTCC mulls incentive scheme for families of organ donors. Times of India [Internet]. 2017 May 4 [cited 2021 May 11]; Available from: https://timesofindia.indiatimes.com/city/ aurangabad/ztcc-mulls-incentive-scheme-for-families-of-organdonors/articleshow/58503777.cms

36. About Us : Jeevasarthakathe [Internet]. [cited 2021 May 11]. Available from: http://www.jeevasarthakathe.karnataka.gov.in/ Website/English/about.html

37. KNOS. Kerala Organ Sharing Registry - Share Organs Save Lives [Internet]. [cited 2021 May 11]. Available from: http:// knos.org.in/Aboutus.aspx

38. Shroff S, Navin S. Mrithasanjeevani - Initiating the Deceased Organ Donation \&Transplantation Programme in Kerala. Indian 
Transpl Newsl [Internet]. 2013 [cited 2021 Apr 28];12. Available from: https://www.itnnews.co.in/indian-transplant-newsl etter/issue38/Mrithasanjeevani-Initiating-the-Deceased-OrganDonation-Transplantation-Programme-in-Kerala-89.htm

39. Mekkodathil A, Asim M, Sathian B, et al. Current scenario of organ donation and transplantation in Kerala, India. Nepal J Epidemiol. 2019;9:759-60.

40. Multi Organ Harvesting Aid Network - [Internet]. [cited 2021 May 6]. Available from: https://www.mohanfoundation.org/who.asp

41. MOHAN Impact on organ transplantation in India [Internet]. [cited 2021 May 6]. Available from: https://www.mohanfound ation.org/MOHAN-Impact-India.asp

42. Shroff S. Indian transplant registry. Indian J Urol [Internet]. Medknow Publications and Media Pvt. Ltd; 2007 [cited 2021 May 6]. p. 272-7. Available from: https://www.indianjurol.com/artic le.asp?issn $=0970-1591$; year $=2007$; volume $=23$;issue $=3 ;$ spage $=$ 272; epage $=277$; aulast $=$ Shroff

43. MOHAN Foundation. NGOs List in India [Internet]. [cited 2021 May 13]. Available from: https://www.mohanfoundation.org/ ngos-list.asp

44. Apollo Hospitals launches Society for Advanced Heart \& Lung Disease - The Hindu [Internet]. [cited 2021 Apr 14]. Available from: https://www.thehindu.com/news/national/tamil-nadu/ apollo-hospitals-launches-society-for-advanced-heart-lung-disea se/article22652463.ece

45. Faceinews.com » Gleneagles Global Health City and Lung Foundation of India Conducts 1st International Conference on Lung Transplantation and Advanced Management of Interstitial Lung Diseases [Internet]. Faceinews. 2018 [cited 2021 May 8]. Available from: http://faceinews.com/?p=13672

46. Apollo hospitals joins with MMC to host India's first exclusive conference on lung transplantation on Saturday [Internet]. United News India. 2018 [cited 2021 May 13]. Available from: http:// www.uniindia.com/ /apollo-hospitals-joins-with-mmc-to-hostindia-s-first-exclusive-conference-on-lung-transplantation-onsaturday/States/news/1585598.html

47. Sunder, Ramesh PT, Kuppuswamy MK, et al. Lung transplantation: the Indian experience and suggested guidelines part II A: the technique of lung transplantation. J Pract Cardiovasc Sci [Internet]. Medknow Publications and Media Pvt. Ltd.; 2020 [cited 2021 Apr 13];6:278. Available from: https://www.j-pcs.org/artic le. asp issn $=2395-5414$; year $=2020 ;$ volume $=6 ;$ issue $=3 ;$ spage $=$ 278 ; epage $=291 ;$ aulast $=$ Sunder

48. Organ Donation Day I National Health Portal Of India [Internet]. [cited 2021 May 13]. Available from: https://www.nhp.gov.in/ organ-donation-day_pg

49. Arora S. 11th National Organ Donation Day [Internet]. Adda 247. 2020 [cited 2021 May 13]. Available from: https://currentaffairs. adda247.com/11th-national-organ-donation-day/

50. Abraham G, Vijayan M, Gopalakrishnan N, et al. State of deceased donor transplantation in India: a model for developing countries around the world. World J Transplant [Internet]. Baishideng Publishing Group Inc.; 2016 [cited 2021 Apr 24];6:331-5. Available from: http://www.ncbi.nlm.nih.gov/pubmed/27358778

51. Kute V, Ramesh V, Shroff S, Guleria S, Prakash J. Deceased-donor organ transplantation in India: current status, challenges, and solutions. Exp Clin Transplant [Internet]. Baskent University; 2020 [cited 2021 Apr 24];18:31-42. Available from: http://www.ectrx. org/detail/supplement/2020/18/1/2/31/0

52. Global Observatory on Donation andTransplantation. WHO-ONT - GODT [Internet]. 2016 [cited 2021 Jun 24]. Available from: http://www.transplant-observatory.org/who-ont/

53. Global Observatory on Donation andTransplantation. International figures on donation and transplantation 2019 [Internet]. Eur. Dir. Qual. Med. Heal. care. 2020 [cited 2021 Jun 23]. p. Volume 25.
Available from: http://www.transplant-observatory.org/wp-conte nt/uploads/2020/10/NEWSLETTER-2020_baja-2.pdf

54. Religion in India [Internet]. Wikipedia. [cited 2021 Jun 24]. Available from: https://en.wikipedia.org/wiki/Religion_in_India

55. Shroff S, Navin S. Hinduism and Organ Donation [Internet]. Indian Transpl. Newsl. 2006 [cited 2021 Jun 21]. p. Vol. VII Issue No. 22/23. Available from: https://www.itnnews.co.in/indian-trans plant-newsletter/issue22/Religion-and-Organ-Donation-339.htm

56. Shroff $S$, Navin S. Islam and organ donation [Internet]. Indian Transpl. Newsl. 2007 [cited 2021 Jun 21]. p. Vol. VII Issue No.25. Available from: https://www.itnnews.co.in/indian-transplantnewsletter/issue25/Religion-and-Organ-Donation-301.htm

57. Shroff S, Navin S. Christianity and organ donation [Internet]. Indian Transpl. Newsl. 2006 [cited 2021 Jun 21]. p. Vol. VII, Issue No.24. Available from: https://www.itnnews.co.in/indiantransplant-newsletter/issue24/Christianity-and-Organ-Donation335.htm

58. Raghuram L, Shroff S. Religious Leaders and Organ Donation an Indian Experience. Transplantation [Internet]. Ovid Technologies (Wolters Kluwer Health); 2017 [cited 2021 Apr 27];101:S59. Available from: http://journals.lww.com/00007890-20170 8002-00104

59. Sunder T, Paul Ramesh T, Madhan Kumar K. Heart \& Heart Lung Transplantation : Indian Scenario. In: Dr Santanu Guha, editor. Cardiol Updat 2015. 1st ed. New Delhi: Jaypee Brothers; 2016. p. $1460-4$.

60. Bumbacea D, Arend SM, Eyuboglu F, et al. The risk of tuberculosis in transplant candidates and recipients: a TBNET consensus statement. Eur Respir J. 2012;40:990-1013.

61. Rahulan V, Jindal A, Attawar S, Balasubramani G, Dutta P. Establishing a Lung Transplant Program in a Resource Constrained Setting. J Hear Lung Transplant [Internet]. Elsevier BV; 2018 [cited 2021 May 3];37:S255. Available from: http://www.jhlto nline.org/article/S1053249818306363/fulltext

62. INSHLT. INdia TRANsplant registry - INTRAN - Google Sheets [Internet]. 2021 [cited 2021 May 6]. Available from: https://docs. google.com/spreadsheets/d/19d9Jcq9IjBxfaiBDX5roZ9z46PEFt y2jlxahyxbluq4/edit\#gid=0

63. Babu KA, Varadarajulu L, K. Madhan Kumar K, Sunder T. Bilateral lung transplantation for idiopathic pulmonary fibrosis in Hermansky Pudlak syndrome. Lung India. 2013;13:44-68.

64. Jindal A, Rahulan V, Balasubramani G, Dutta P, Attawar S. Pulmonary alveolar microlithiasis: A rare disease treated with lung transplantation, first case from India. Lung India [Internet]. Medknow; 2019 [cited 2020 Nov 9];36:546. Available from: /pmc/artic les/PMC6852219/?report=abstract

65. Prasad KT, Sehgal IS, Dhooria S, et al. Experience of the first lung transplantation performed in public sector in India. Lung India [Internet]. Wolters Kluwer Medknow Publications; 2019 [cited 2021 Apr 6];36:66-9. Available from: http://www.ncbi.nlm.nih. gov/pubmed/30604708

66. Prasad K, Sehgal I, Dhooria S, et al. Underutilization of potential donors for lung transplantation at a tertiary care center in North India. Lung India [Internet]. Wolters Kluwer Medknow Publications; 2019 [cited 2020 Nov 9];36:399-403. Available from: /pmc/ articles/PMC6710964/?report=abstract

67. Prasad KT, Singh Sehgal I, Dhooria S, et al. Patient characteristics and outcome of end-stage lung diseases referred for lung transplantation in North India. Lung India [Internet]. Wolters Kluwer Medknow Publications; 2018 [cited 2020 Nov 9];35:290-4. Available from: https://pubmed.ncbi.nlm.nih.gov/29970766/

68. Tendolkar M, Tyagi R, Jindal A, Attawar S, Handa A. First lung transplant recipient of Indian armed forces. J Mar Med Soc. Medknow; 2020;22:245. 
69. Madhu Sankar N, Ramani SS, Cherian KM. Anaesthetic and perioperative management of lung transplantation. Indian J Anaesth. 2017;61:173-5.

70. Kanagarajan N, Madhu Sankar N, Benjamin N, Cherian K. Anaesthetic management and preservation of donor heart lung for transplantation. Indian J Anaesth. 2004;48:142-4.

71. Rahulan V, Yadav P, Jindal A, et al. First Series of Combined Heart \& Lung Transplantation from India. J Heart Lung Transplant [Internet]. NLM (Medline); 2020 [cited 2021 May 3];39:S387. Available from: http://www.jhltonline.org/article/ S1053249820305222/fulltext

72. Bhosekar P, Chaubey AK. Hyderabad doctors perform rare doublelung transplant on post-COVID lung fibrosis patient [Internet]. India News I Zee News. 2020 [cited 2021 May 7]. Available from: https:// zeenews.india.com/india/hyderabad-doctors-perform-rare-doublelung-transplant-on-post-covid-lung-fibrosis-patient-2330267.html

73. Sunder T. Extracorporeal membrane oxygenation and lung transplantation [Internet]. Indian J. Thorac. Cardiovasc. Surg. Springer; 2021 [cited 2021 Apr 23]. p. 327-37. Available from: https://doi. org/10.1007/s12055-020-01099-5

74. Rahulan V, Shah U, Yadav P, et al. Challenges, experiences, and postoperative outcomes in setting up first successful lung transplant unit in India. Lung India [Internet]. Medknow Publications and Media Pvt. Ltd.; 2021 [cited 2021 May 1];38:216. Available from: http://www.lungindia.com/text.asp?2021/38/3/216/315298

75. COVID-19 lockdown in India - Wikipedia [Internet]. [cited 2021 May 7]. Available from: https://en.wikipedia.org/wiki/COVID19_lockdown_in_India

76. NOTTO-DGHS. NATIONAL TRANSPLANT SPECIFIC GUIDANCE FOR COVID-19 [Internet]. 2020. Available from: https://www.gaeba.org/2020/alert-coron avirus-2019-ncov-and-ocular-tissue-
77. Special Correspondent. Two patients undergo lung transplant at Apollo Hospitals [Internet]. The Hindu. 2020 [cited 2021 May 7]. Available from: https://www.thehindu.com/sci-tech/health/twopatients-undergo-lung-transplant-at-apollo-hospitals/article328 03714.ece

78. Krishna Gokhale AG, Balakrishnan KR, Punnen J, et al. Recommendations of the INSHLT task force for thoracic organ transplant during COVID-19 pandemic in India. J Pract Cardiovasc Sci. 2020;6:108-10.

79. Agrawal S. Doctors in Hyderabad perform India's first double lung transplant on recovered COVID patient [Internet]. The Print. 2020 [cited 2021 Apr 23]. Available from: https://theprint.in/ health/doctors-in-hyderabad-perform-indias-first-double-lungtransplant-on-recovered-covid-patient/501590/

80. Rai A. Chennai doctors perform Asia's first lung transplant on Covid-19 patient [Internet]. The Hindustan Times. 2020 [cited 2021 May 7]. Available from: https://www.hindustantimes.com/ india-news/brain-dead-man-breathes-new-life-into-covid-19-patie nt-with-severe-lung-infection/story-UUVnm1GL1Aqv4b1j9MIL WN.html

81. HT Correspondent. Max hospital conducts Delhi's first lung transplant in Covid-19 patient. Hindustan Times [Internet]. 2020 [cited 2021 May 7]; Available from: https://www.hindustantimes.com/ delhi-news/max-hospital-conducts-delhi-s-first-lung-transplantin-covid-19-patient/story-GHdQ0V5n0TtdwPKmfD5EEL.html

Publisher's note Springer Nature remains neutral with regard to jurisdictional claims in published maps and institutional affiliations. 